\title{
Water and electrolyte exchanges of obese patients on a reducing regimen
}

\author{
By R. PASSMORE, J. A. STRONG AND FIONA J. RITCHIE \\ Departments of Physiology and Medicine, University of Edinburgh \\ and the Western General Hospital
}

(Received 24 March 1958-Revised 13 August 1958)

Fat people who attempt to reduce their weight by dieting are often successful at first. After a short period of rapid weight loss, progress is usually less well maintained and may slow down or come to a complete stop before the desired new weight is reached. This frequently happens even when the patient has been carefully supervised and has been collaborating conscientiously. The obese normally carry a moiety of body water which they rapidly lose early in the course of treatment by strict dieting (initial dehydration), but thereafter they may increase their relative body water content (secondary water retention) (Strong, Passmore \& Ritchie, 1958; Passmore, Strong \& Ritchie, $195^{8}$ ). In these papers we gave quantitative assessments of the initial water losses and subsequent water retention by seven obese patients, each of whom was studied for 6 weeks on a strictly controlled and rigorous reducing regimen. In five of these patients, a complete water balance was derived for the whole period. It comprised the total fluid intake, the metabolic water, the urine, the faecal water and the evaporative water loss. In addition, the sodium and potassium contents of the diet and of the urine and faeces were measured. This paper gives the results of these studies.

\section{METHODS}

The clinical histories of the five patients (Mrs L., Miss McN., Miss B., Miss M. and $\mathrm{MrW}$.) and the details of their dietary regimens and physical activities are recorded in a previous paper (Strong et al. $\left.195^{8}\right)$. The changes in their body water $\left(\Delta \mathrm{H}_{2} \mathrm{O}\right)$ during the reducing regimen were calculated from the equation:

$\Delta \mathrm{H}_{2} \mathrm{O}=$ change of body-weight - tissue protein metabolized - tissue fat metabolized.

The tissue protein metabolized was calculated from the nitrogen balance and the tissue fat metabolized from the energy balance (Passmore et al. 1958).

Here we present values for the full water balance calculated as follows:

$\Delta \mathrm{H}_{2} \mathrm{O}=$ (ingested water + metabolic water)

$$
- \text { (urinary water }+ \text { faecal water + evaporative water). }
$$

Ingested water. All liquids consumed were measured. Portions of replicate homogenized diets were dried to constant weight on a water bath and then in a desiccator and the water in the food was determined by the difference in weight.

Metabolic water. It was determined from the total amounts of protein, fat and carbohydrate in the diets, together with the amounts of tissue protein and tissue fat 
metabolized, which had already been calculated (Passmore et al. 1958). The water of oxidation of $\mathrm{I} g$ protein, carbohydrate and fat was taken as $0.4 \mathrm{I}, 0.60$ and $\mathrm{I} .07 \mathrm{~g}$ respectively.

Urinary water. See p. 19.

Faecal water. Portions of faeces were dried to constant weight.

Evaporative water. It's weight was derived from the invisible weight loss by adding the weight of oxygen consumed and subtracting the weight of carbon dioxide produced. These weights of oxygen and carbon dioxide were calculated from the metabolic mixture, determined by adding the losses of tissue protein and fat to the dietary protein, fat and carbohydrate. As the metabolic mixtures were composed predominantly of fat (the respiratory quotients were around o.70 (see Table 3, Strong et al. 1958)), weights of oxygen approximated very closely to weights of carbon dioxide. This correction for the invisible weight loss was therefore small.

The invisible weight loss was determined from the equation:

Invisible weight loss $=$ change of body-weight + weight of solids and

liquids ingested - weight of urine and faeces.

These values are easily obtained by simple measurement.

The calculation of the full water balance might be thought to provide a check on the water balance determined previously from the changes in body composition. It is not so, as the same calculation of the metabolic mixture is common to both determinations. That the two methods should give identical results can be proved by the following calculations, where $P=$ protein, $F=$ fat, $C=$ carbohydrate, $S=$ salts, $R=$ roughage, $W=$ weight and, written as subscript, $i=$ ingested, $u=$ urinary, $f=$ faecal, $t=$ tissue, $m=$ metabolic, $e=$ evaporative.

Changes in body water are calculated from changes in body composition as follows:

$$
\Delta \mathrm{H}_{2} \mathrm{O}=\Delta W_{t}-\Delta P_{t}-\Delta F_{t}-\Delta C_{t}-\Delta S_{t}
$$

In practice $\Delta C_{t}$ and $\Delta S_{t}$ are assumed to be negligible in comparison with the other components.

Changes in total body water are calculated from the full water balance as follows:

$$
\Delta \mathrm{H}_{2} \mathrm{O}=\left(\mathrm{H}_{2} \mathrm{O}\right)_{i}+\left(\mathrm{H}_{2} \mathrm{O}\right)_{m}-\left(\mathrm{H}_{2} \mathrm{O}\right)_{u}-\left(\mathrm{H}_{2} \mathrm{O}\right)_{f}-\left(\mathrm{H}_{2} \mathrm{O}\right)_{e}
$$

but $\left(\mathrm{H}_{2} \mathrm{O}\right)_{i}$ is obtained from

$$
\left(\mathrm{H}_{2} \mathrm{O}\right)_{i}=W_{i}-P_{i}-F_{i}-C_{i}-S_{i}-R_{i}
$$

and $\left(\mathrm{H}_{2} \mathrm{O}\right)_{m}$ from the equation of the metabolic mixture

$$
(\mathrm{I}-a)\left(P_{i}-P_{f}-\Delta P_{t}\right)+\left(C_{i}-C_{f}-\Delta C_{t}\right)+\left(F_{i}-F_{f}-\Delta F_{t}\right)+\left(\mathrm{O}_{2}\right)_{m}=\left(\mathrm{H}_{2} \mathrm{O}\right)_{m}+\left(\mathrm{CO}_{2}\right)_{m}
$$

where $a$ is that portion of the protein molecule that is not oxidized.

Now $\left(\mathrm{H}_{2} \mathrm{O}\right)_{u}$ is given by

$\left(\mathrm{H}_{2} \mathrm{O}\right)_{f}$ by

$$
\begin{gathered}
\left(\mathrm{H}_{2} \mathrm{O}\right)_{u}=W_{u}-a\left(P_{i}-P_{f}-\Delta P_{t}\right)-\left(S_{i}-\Delta S_{t}\right) \\
\left(\mathrm{H}_{2} \mathrm{O}\right)_{f}=W_{f}-P_{f}-F_{f}-C_{f}-R_{i} \\
\left(\mathrm{H}_{2} \mathrm{O}\right)_{e}=I W L+\left(\mathrm{O}_{2}\right)_{m}-\left(\mathrm{CO}_{2}\right)_{m}
\end{gathered}
$$

and $\left(\mathrm{H}_{2} \mathrm{O}\right)_{e}$ by

but $I W L$ (invisible weight loss) is measured indirectly thus

$$
I W L=W_{i}-\Delta W_{t}-W_{u}-W_{f}
$$


Now by substituting in equation (2) from equations (3)-(8) we derive again equation ( $\mathrm{r})$. Thus the two equations are not independent. $\Delta\left(\mathrm{H}_{2} \mathrm{O}\right)_{t}$ calculated from values derived from equation (2) must agree with the value for $\Delta\left(\mathrm{H}_{2} \mathrm{O}\right)_{t}$ derived from equation (I). If the two values do not agree, then there is an error in collection of the basic values.

When the calculations were complete, we found that the value of $\Delta \mathrm{H}_{2} \mathrm{O}$ obtained from the full water balance was always about $20-30 \mathrm{~g}$ /day less than that calculated from the change in body-weight. After much thought and inquiry, we discovered that this discrepancy was due to equating volume of urine with weight of urinary water. Trapp ( 1850 ) pointed out that urinary solids cause expansion of urinary volume. For calculating the solids in $\mathrm{I} l$. urine he set out the formula:

$$
\text { Urinary solids }(g / 1 .)=(1000 \times \text { sp.gr. }-1000) \times 2 \text {. }
$$

Our patients usually passed urine of high specific gravity and so the volume of urinary water was significantly below that of urine. A correction for this factor has been made in the results presented in Table 1 . In this table, all the figures have been rounded off and the changes in body water are the same as previously recorded (Table 3, Passmore et al. 1958). Apart from the conversion of the volumes of urine into volumes of urinary water, this equating of the two sets of results did not involve changes larger than $15 \mathrm{~g}$ in any one balance, which is certainly within the limits of accuracy of the observations.

Sodium and potassium. They were determined with a flame photometer in food, faeces and urine. The food and faeces were dried at $100^{\circ}$ for the determination of water content and subsequently ashed at $500^{\circ}$. The ash was extracted with I ml. conc. $\mathrm{HCl}$ and diluted to the appropriate volume.

\section{RESULTS AND DISCUSSION}

\section{Water balance}

Table I sets out the water balances for each of the five subjects. It will be seen that during the first experimental period each subject had a large negative balance, but in subsequent periods balances were less negative and were sometimes even positive. Of the five components that make up the water balance, two (the metabolic and faecal water) are relatively small and constant, as a brief inspection of Table $\mathrm{I}$ shows. The other three components (ingested, urinary and evaporative water) are larger and more variable and share responsibility for the regulation of body-water content. Their relation to changes in body water are shown in Fig. 1 .

Urinary water. The view is commonly held by clinicians (Newburgh, 1950) that the rapid loss of weight which may occur from time to time in obese patients under treatment can be attributed to diuresis. Conversely, their failure to lose weight may be ascribed to water retention by the kidneys.

This conception of the causes of changes in weight would not apply to most of our patients. Fig. I shows the relation between changes of body-water content and the three principal routes of water exchange. In Mrs L., Miss McN. and Miss B. there 
was obviously little association between urinary water and the loss of body water. In Miss M., however, there was a positive correlation between these two quantities which approached significance $(r=0.65 ; 0.1>P>0.05)$; but for $\mathrm{Mr} \mathrm{W}$. the relation was not significant. These correlations were calculated for all the periods, including those when urea was given. It would seem therefore that, with the exception of Miss M., changes of body water in these patients were not associated with marked diuresis or antidiuresis.

Table I. Water exchanges (ml./day) of obese patients on a reducing regimen

\begin{tabular}{|c|c|c|c|c|c|c|c|}
\hline Subject & Days & $\begin{array}{c}\text { Water } \\
\text { balance }\end{array}$ & $\begin{array}{l}\text { Ingested } \\
\text { water }\end{array}$ & $\begin{array}{l}\text { Metabolic } \\
\text { water }\end{array}$ & $\begin{array}{l}\text { Urinary } \\
\text { water }\end{array}$ & $\begin{array}{l}\text { Faecal } \\
\text { water }\end{array}$ & $\begin{array}{c}\text { Evaporative } \\
\text { water }\end{array}$ \\
\hline Mrs L. & $\begin{array}{c}1-7 \\
8-14 \\
15-21 * \\
22-28^{*} \\
29-35 \\
36-42\end{array}$ & $\begin{array}{r}-440 \\
-240 \\
+130 \\
+70 \\
+100 \\
-150\end{array}$ & $\begin{array}{l}1770 \\
1530 \\
1280 \\
1240 \\
1240 \\
1300\end{array}$ & $\begin{array}{l}390 \\
390 \\
370 \\
310 \\
360 \\
310\end{array}$ & $\begin{array}{l}55^{\circ} \\
630 \\
500 \\
580 \\
45^{\circ} \\
700\end{array}$ & $\begin{array}{l}60 \\
70 \\
40 \\
20 \\
20 \\
10\end{array}$ & $\begin{array}{r}1990 \\
1460 \\
980 \\
880 \\
1030 \\
1050\end{array}$ \\
\hline Miss McN. & $\begin{array}{l}1-7 \\
8-14 \\
15-21 \\
22-28 \\
29-35 \\
36-42 \dagger\end{array}$ & $\begin{array}{l}-300 \\
-10 \\
+10 \\
-50 \\
-10 \\
+50\end{array}$ & $\begin{array}{l}1670 \\
1830 \\
1800 \\
1550 \\
1530 \\
1580\end{array}$ & $\begin{array}{l}380 \\
380 \\
380 \\
370 \\
340 \\
360\end{array}$ & $\begin{array}{l}700 \\
680 \\
540 \\
480 \\
440 \\
55^{\circ}\end{array}$ & $\begin{array}{l}90 \\
30 \\
30 \\
30 \\
30 \\
30\end{array}$ & $\begin{array}{l}1560 \\
1510 \\
1600 \\
1460 \\
1410 \\
1310\end{array}$ \\
\hline Miss B. & $\begin{array}{c}1-7 \\
8-14 \\
15-21 \\
22-28 \\
29-35 \\
35-42\end{array}$ & $\begin{array}{r}-390 \\
+40 \\
+50 \\
+10 \\
+110 \\
-10\end{array}$ & $\begin{array}{l}1370 \\
1420 \\
1200 \\
1210 \\
1240 \\
1200\end{array}$ & $\begin{array}{l}250 \\
330 \\
340 \\
340 \\
370 \\
340\end{array}$ & $\begin{array}{l}630 \\
430 \\
370 \\
590 \\
570 \\
700\end{array}$ & $\begin{array}{l}50 \\
40 \\
20 \\
10 \\
20 \\
30\end{array}$ & $\begin{array}{r}1330 \\
1240 \\
1100 \\
940 \\
910 \\
820\end{array}$ \\
\hline Miss M. & $\begin{array}{l}1-5 \\
6-10 \\
1 I-15 \\
16-20 \\
2 I-25 \\
26-30 \S \\
3 I-35 \\
36-40 \ddagger \\
4 I-45\end{array}$ & $\begin{array}{r}-570 \\
-160 \\
+70 \\
+240 \\
-20 \\
-140 \\
+150 \\
+100 \\
-340\end{array}$ & $\begin{array}{l}155^{\circ} \\
1350 \\
1600 \\
1940 \\
1630 \\
1740 \\
1990 \\
1510 \\
1950\end{array}$ & $\begin{array}{l}400 \\
380 \\
390 \\
380 \\
390 \\
390 \\
360 \\
380 \\
330\end{array}$ & $\begin{array}{l}570 \\
450 \\
380 \\
410 \\
540 \\
580 \\
300 \\
370 \\
800\end{array}$ & $\begin{array}{l}30 \\
40 \\
20 \\
60 \\
70 \\
40 \\
90 \\
110 \\
160\end{array}$ & $\begin{array}{l}1920 \\
1400 \\
1520 \\
1610 \\
1430 \\
1650 \\
1810 \\
1310 \\
1660\end{array}$ \\
\hline Mr W. & $\begin{array}{l}I-5 \\
6-10 \\
11-15 \\
16-20 \ddagger \\
21-25 \\
26-30 \$ \\
31-35 \$ \\
36-40\end{array}$ & $\begin{array}{r}-580 \\
+200 \\
-90 \\
+180 \\
-210 \\
-140 \\
+60 \\
0\end{array}$ & $\begin{array}{l}1840 \\
1770 \\
1580 \\
1840 \\
1630 \\
2720 \\
2160 \\
1940\end{array}$ & $\begin{array}{l}430 \\
430 \\
410 \\
410 \\
370 \\
380 \\
360 \\
370\end{array}$ & $\begin{array}{r}\text { I I 10 } \\
730 \\
530 \\
430 \\
880 \\
1620 \\
900 \\
750\end{array}$ & $\begin{array}{l}80 \\
30 \\
50 \\
20 \\
60 \\
40 \\
50 \\
40\end{array}$ & $\begin{array}{l}\text { I660 } \\
1240 \\
1500 \\
1620 \\
1270 \\
1580 \\
1510 \\
1520\end{array}$ \\
\hline
\end{tabular}

* Diet supplied about: protein 50 , carbohydrate 35 , fat $15 \mathrm{~g} / \mathrm{day}$.

+ Diet supplied about: protein 80 , carbohydrate $5 \circ$, fat $30 \mathrm{~g} /$ day.

$\ddagger$ Diet supplied about: protein 25, carbohydrate 200 , fat $10 \mathrm{~g} /$ day.

$\S$ I $5 \mathrm{~g}$ urea given daily.

In other periods, the diet supplied about: protein 25 , carbohydrate 40 , fat $15 \mathrm{~g} /$ day.

Evaporative water losses. Observations by Kekwick \& Pawan (1956) suggested that water lost by evaporation might be an important factor in determining changes in the body water of obese patients. They showed that on diets providing $1000 \mathrm{Cal}$, of which $90 \%$ was derived from carbohydrate, invisible weight losses were much less 
than on isocaloric diets in which fat was substituted for carbohydrates. It is clear from Fig. I that in our patients evaporative water losses were very variable though only in Mrs L. was the correlation with the loss of body water close and statistically significant $(r=+0.80 ; 0.02>P>0.01)$. This finding contrasts with Newburgh's ( 1950 ) that in healthy subjects and in diabetics losses of water by evaporation were remarkably constant and accounted for between 23 and $25 \%$ of the total calories dissipated. In our investigation calorie expenditure was relatively constant in each patient (see Table 3, Passmore et al. 1958) and it might therefore have been expected that evaporative water losses would have been similarly uniform.

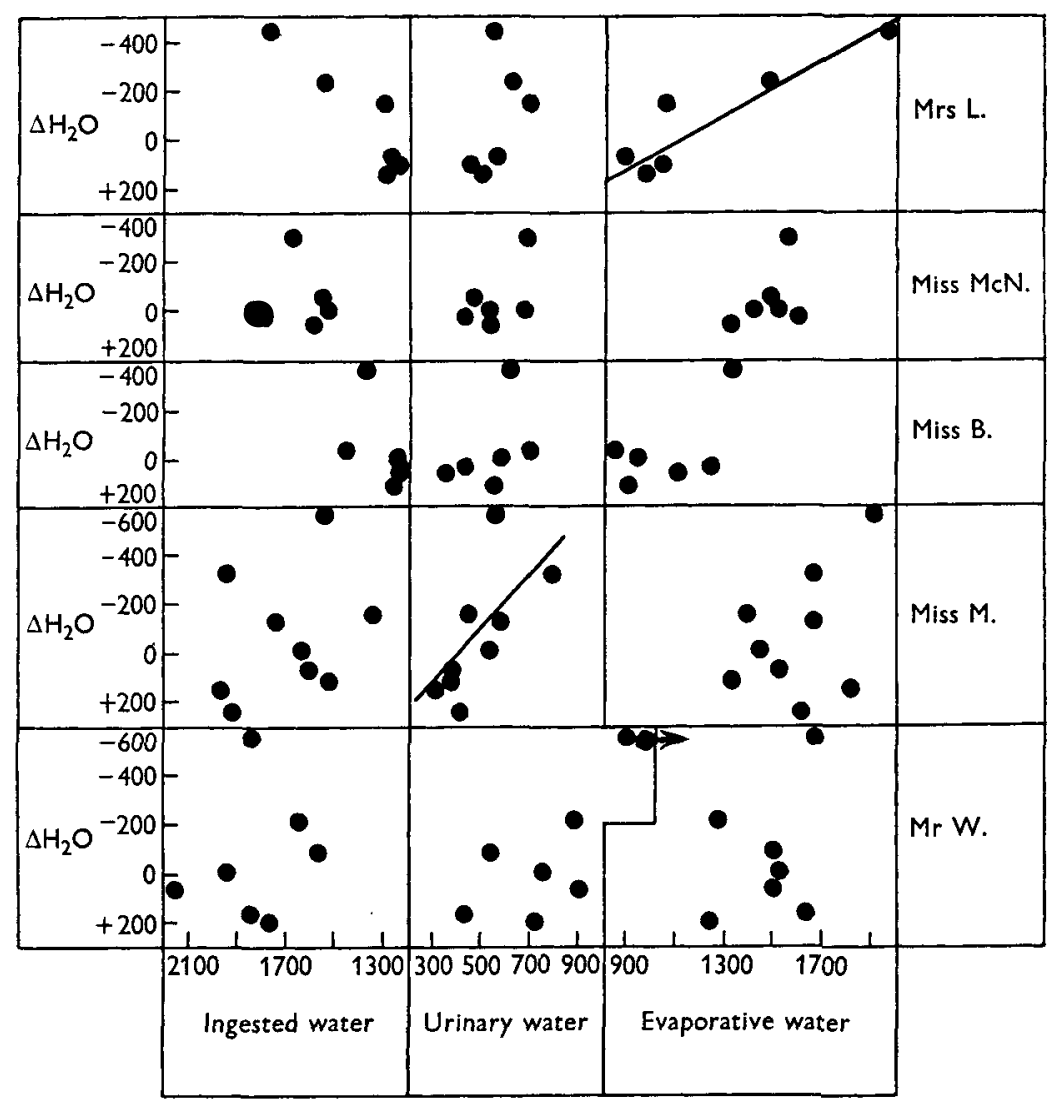

Fig. I. Relation between the change in body water $\left(\Delta \mathrm{H}_{2} \mathrm{O}\right)$ and ingested water, urinary water and evaporative water. Each point represents a daily mean for observation periods lasting 7 days (Mrs L., Miss McN. and Miss B.) or 5 days (Miss M. and Mr W.). $\bullet \rightarrow$, aberrant value.

The variations we have observed might be due to changes in environmental temperature or in visible sweat loss during walking exercises. We have no records of the temperature of the hospital ward throughout these observations, but we believe that there were no considerable changes during successive periods of observation in each patient; these were also limited to a relatively small part of the season of a year. The patients did not appear to sweat unduly. During the periods of exercise, 
evaporative water losses were low; they were less than would be predicted from Newburgh's (1950) observations on normal people - and much less for Mrs L. and Miss B. Furthermore, no association was found between evaporative water losses and calories expended during walking.

We consider, therefore, that irregularities in the evaporative water losses are real, and that in this respect obese patients differ markedly from Newburgh's subjects. We know of no accurate studies of temperature regulation in obese patients, and our results, together with those of Kekwick \& Pawan (1956), suggest that such an investigation might be profitable.

During these studies, two patients were given high-carbohydrate diets similar to those prescribed by Kekwick \& Pawan (1956). On this diet, Miss M. showed a fall in evaporative water loss and a positive water balance (Table $\mathbf{I}$ ). This result therefore agrees with the findings of Kekwick \& Pawan. By contrast, Mr W. had a high rate of evaporative water loss on this diet though he also was in positive water balance.

Table 2. Energy intake and invisible weight loss and heat exchanges of obese patients on a reducing regimen

\begin{tabular}{|c|c|c|c|c|c|}
\hline Day & $\begin{array}{c}\text { Energy } \\
\text { intake } \\
\text { (Cal./day) }\end{array}$ & $\begin{array}{l}\text { Weight } \\
\text { (kg) }\end{array}$ & $\begin{array}{c}\text { Metabolic } \\
\text { rate } \\
\text { (Cal. } / \mathrm{min})\end{array}$ & $\begin{array}{l}\text { Invisible } \\
\text { weight loss } \\
(\mathrm{g} / \mathrm{h})\end{array}$ & $\begin{array}{l}\text { Evaporative } \\
\text { heat loss as } \\
\text { percentage } \\
\text { of total }\end{array}$ \\
\hline \multicolumn{6}{|c|}{ Miss M. (sitting) } \\
\hline I & 400 & $118 \cdot 7$ & $I \cdot 40$ & 33 & 23 \\
\hline 3 & 400 & I $16 \cdot 4$ & $x \cdot 72$ & 44 & 24 \\
\hline ro & 400 & $112 \cdot 6$ & $I \cdot 4 I$ & 30 & 21 \\
\hline 37 & $\begin{array}{c}1000 \\
90 \% \text { carbohydrate }\end{array}$ & 105.8 & $I \cdot 33$ & 24 & I7 \\
\hline $3^{8}$ & $\begin{array}{l}\text { I000 } \\
90 \% \text { carbohydrate }\end{array}$ & $105 \cdot 4$ & $I \cdot 33$ & 23 & 17 \\
\hline \multicolumn{6}{|c|}{ Mr W. (sitting) } \\
\hline 0 & (Home diet) & $13 I \cdot I$ & $2 \cdot 15$ & 57 & 26 \\
\hline 4 & 400 & $126 \cdot 9$ & $1 \cdot 75$ & $4 I$ & 22 \\
\hline 7 & 400 & $125 \cdot 6$ & $\mathrm{I} \cdot 54$ & 35 & 22 \\
\hline 18 & $\begin{array}{c}\text { I } 000 \\
90 \% \text { carbohydrate }\end{array}$ & 123.0 & $I \cdot 4 I$ & 52 & 36 \\
\hline r9 & $\begin{array}{c}1000 \\
90 \% \text { carbohydrate }\end{array}$ & $122 \cdot 8$ & $x \cdot 60$ & 55 & 33 \\
\hline
\end{tabular}

The values for evaporative water loss recorded in Table I are the means for 5 -day periods, during which daily weight changes were recorded on a balance only sensitive to $3 \circ \mathrm{g}$. A few values were obtained for both subjects when sitting quietly for $3 \mathrm{~h}$, with a balance which could register changes in weight of as little as $2 \mathrm{~g}$. The results are presented in Table 2 and confirm the changes shown in Table I. Miss M. showed a fall and $\mathrm{Mr} \mathrm{W}$. an increase in invisible weight loss when on the high-carbohydrate diet.

Further studies on the evaporative water losses of obese patients under conditions where the environmental temperature is strictly controlled are obviously needed.

Ingested water. There were no significant correlations between the amount of water drunk and the calculated water balance. All the patients had free access to water and 
were instructed to drink as much as they liked. It is possible, however, that they may have been influenced by previous advice (commonly given to obese patients) to restrict their water intake. Certainly the intakes were low. Our findings suggest that restriction of fluid intake is unlikely to have any effect in increasing the rate of weight loss.

\section{Electrolyte balance}

Table 3 sets out the basic values, and Table 4 shows the estimated changes in total body values for water, $\mathrm{N}, \mathrm{K}$ and $\mathrm{Na}$ for each subject during the period of initial dehydration and during the period of secondary water retention. The figures for $\mathrm{N}$ are calculated from the data in Table i of Passmore et al. (1958) which make no allowance for losses through the skin. For $\mathrm{N}$ and $\mathrm{K}$ these are not likely to be important but skin losses of $\mathrm{Na}$ may well have been appreciable.

Table 3. Electrolyte exchanges (m-equiv./day) of obese patients on a reducing regimen

\begin{tabular}{|c|c|c|c|c|c|c|c|c|}
\hline \multirow[b]{2}{*}{ Subject } & \multirow[b]{2}{*}{ Days } & \multicolumn{4}{|c|}{ Sodium } & \multicolumn{3}{|c|}{ Potassium } \\
\hline & & Diet & $\begin{array}{c}\text { Table } \\
\text { salt }\end{array}$ & Urine & Faeces & Diet & $\overbrace{\text { Urine }}$ & Faeces \\
\hline \multirow[t]{6}{*}{ Mrs L. } & $1-7$ & 6 & 48 & 57 & 2 & 37 & 36 & 9 \\
\hline & $8-14$ & 8 & 24 & 57 & I & 44 & 47 & II \\
\hline & $15-21$ & $x_{5}$ & I9 & I 5 & 2 & 37 & 37 & 14 \\
\hline & $22-28$ & I 5 & 24 & 37 & I & 42 & $3^{6}$ & 3 \\
\hline & $29-35$ & 26 & 24 & 29 & I & 40 & 35 & 3 \\
\hline & $36-42$ & I9 & 26 & 54 & $\circ$ & 30 & 24 & 3 \\
\hline \multirow[t]{6}{*}{ Miss $\mathrm{McN}$. } & $1-7$ & - & - & 62 & 3 & 26 & 40 & 5 \\
\hline & $8-14$ & 26 & 68 & 73 & I & 29 & 31 & 3 \\
\hline & $15-2 I$ & 32 & 68 & 54 & I & 34 & 33 & 5 \\
\hline & $22-28$ & 28 & 68 & 78 & I & 35 & $3^{6}$ & 6 \\
\hline & $29-35$ & 40 & 68 & 54 & I & 34 & 35 & 5 \\
\hline & $36-42$ & 74 & 39 & 109 & $\mathrm{r}$ & 36 & 29 & 4 \\
\hline \multirow[t]{6}{*}{ Miss B. } & $1-7$ & 40 & 24 & 66 & $\mathbf{r}$ & 34 & 43 & 7 \\
\hline & $8-14$ & 30 & I9 & $3 \mathrm{I}$ & I & $3 I$ & 35 & 8 \\
\hline & I $5-21$ & 29 & 18 & 25 & 0 & 26 & 33 & 3 \\
\hline & $22-28$ & 20 & 17 & 24 & ○ & 28 & 32 & 2 \\
\hline & $29-35$ & 29 & 22 & 23 & 0 & 30 & 35 & 5 \\
\hline & $3^{6-42}$ & $3 I$ & 24 & 52 & 0 & 32 & 40 & 5 \\
\hline \multirow[t]{9}{*}{ Miss $\mathbf{M}$. } & $x-5$ & I4 & - & 47 & I & 20 & 47 & 3 \\
\hline & $6-10$ & I 5 & - & 6 & I & 20 & 35 & 3 \\
\hline & $I I-15$ & 14 & - & 3 & I & 20 & 24 & 3 \\
\hline & I6-20 & 21 & 17 & 4 & I & 48 & 29 & 8 \\
\hline & $2 I-25$ & 27 & 17 & 25 & 3 & 35 & 32 & 8 \\
\hline & $26-30$ & 24 & 17 & 44 & I & 42 & 42 & 6 \\
\hline & $31-35$ & 25 & 17 & 22 & 6 & 42 & 28 & 7 \\
\hline & $3^{6-40}$ & $5^{8}$ & 17 & 57 & IO & 45 & 29 & 8 \\
\hline & $41-45$ & 35 & 17 & $8 I$ & I I & 42 & 35 & 8 \\
\hline \multirow[t]{8}{*}{ Mr W. } & $I-5$ & 22 & 14 & 54 & I & 48 & 50 & I I \\
\hline & $6-10$ & 32 & $4 I$ & 51 & $\mathrm{I}$ & 40 & 44 & 6 \\
\hline & I $1-15$ & 37 & 34 & 48 & 3 & 44 & 26 & 10 \\
\hline & $16-20$ & 59 & 45 & 57 & $\mathrm{r}$ & 56 & 34 & $\mathbf{I}$ \\
\hline & $21-25$ & 23 & 45 & 80 & 5 & 42 & 28 & 6 \\
\hline & $26-30$ & 37 & 34 & 113 & 2 & 44 & $3^{8}$ & 2 \\
\hline & $31-35$ & 26 & 38 & 53 & 3 & 40 & 27 & 3 \\
\hline & $36-40$ & 37 & $4 I$ & 52 & I & 44 & 24 & 3 \\
\hline
\end{tabular}


Table 4 shows that during the period of initial dehydration there were negative balances of $\mathrm{N}, \mathrm{K}$ and $\mathrm{Na}$. Actual negative $\mathrm{Na}$ balances must have been larger than recorded owing to neglect of losses through the skin. These findings are consistent with the view that both intracellular and extracellular fluid was being lost during this period.

Table 4. Body changes in water, nitrogen, potassium and sodium of obese patients on a reducing regimen

\begin{tabular}{|c|c|c|c|c|c|}
\hline Subject & Days & $\begin{array}{c}\mathrm{H}_{2} \mathrm{O} \\
(1 .)\end{array}$ & $\begin{array}{l}\mathrm{N} \\
(\mathrm{g})\end{array}$ & $\underset{\text { (m-equiv.) }}{\mathrm{K}}$ & $\stackrel{\mathrm{Na}}{\text { (m-equiv. }}$ \\
\hline \multicolumn{6}{|c|}{ First period: dehydration } \\
\hline Irs L. & $I-I 4$ & $-4 \cdot 8$ & -67 & - I 54 & -217 \\
\hline liss $\mathrm{McN}$. & $1-7$ & $-2 \cdot I$ & -56 & -133 & - \\
\hline iss $B$. & $I-7$ & $-2 \cdot 7$ & -41 & -112 & -21 \\
\hline Tiss $\mathrm{M}$. & I-IO & $-3 \cdot 7$ & -55 & -240 & -130 \\
\hline Ir W. & $1-5$ & $-2 \cdot 9$ & -47 & -65 & -95 \\
\hline \multicolumn{6}{|c|}{ Second period: water retention } \\
\hline s L. & I $5-42$ & $+I \cdot I$ & -34 & -42 & +203 \\
\hline Iiss $\mathrm{McN}$. & $8-42$ & o & -66 & -133 & +966 \\
\hline liss $\mathrm{B}$. & $8-42$ & $+1 \cdot 4$ & -107 & -357 & $+5^{8} \mathrm{I}$ \\
\hline Tiss $M$. & I $1-45$ & 0 & -55 & +35 & +180 \\
\hline Ir W. & $6-40$ & 0 & -112 & +290 & +295 \\
\hline
\end{tabular}

During the period of secondary water retention, $\mathrm{N}$ balances were negative and $\mathrm{Na}$ balances positive in all subjects. Owing to skin losses, the $\mathrm{Na}$ retention would not be as large as recorded. However, Miss McN. and Miss B. both showed considerable losses of $\mathrm{K}$ and gains of $\mathrm{Na}$ during this period. It is reasonable to conclude that these changes represented gains of extracellular water and losses of intracellular water, each of the order of $1-3$ l. for the whole period of 35 days. With Mrs L. and Miss M., the electrolyte balances were small (after allowance for unrecorded $\mathrm{Na}$ losses through the skin). Presumably both intracellular and extracellular water remained approximately constant despite losses in $\mathrm{N}$ and fat (for data see Table $\mathrm{I}$, Passmore et al. 1958). There is no obvious explanation for the positive potassium balance of $\mathrm{Mr} \mathrm{W}$.

\section{CONCLUSION}

We have studied the variations in body water of obese patients on a reducing regimen. Changes in water intake appear to be unrelated to rates of loss of body water, and fluctuation in urine output by most patients can only account for an inconstant proportion of the changes in body water. Evaporative water losses were very variable; in one patient they were more closely related to changes in total body water than were the changes in urine output. The changes in evaporative water losses might be associated with disturbances in temperature regulation, and it is clearly important to study these losses under conditions in which environmental temperature can be adequately controlled.

\section{SUMMARY}

I. The water and electrolyte exchanges were recorded in five patients on a reducing regimen lasting over 40 days.

2. Losses and gains of total body water were not associated with changes in fluid intake. They could only be partly explained by variations in the urinary output. In one 
patient, variations in evaporative water losses appeared to be important, and the skin may have a role in determining the water balance.

3. The electrolyte exchanges indicated that during initial periods of dehydration there were losses of both intracellular and extracellular water. In subsequent periods, water retention was found to be associated with increases of extracellular water, despite probable continuing losses of intracellular water.

We are indebted to Miss N. Stokoe, B.Sc. and Dr Helen Stojicevic for assistance with the chemical analyses. We wish to thank the Medical Research Council for a personal grant to one of us (F.J.R.) and also for an expense grant.

\section{REFERENCES}

Kekwick, A. \& Pawan, G. L. S. (1956). Lancet, 271, I55.

Newburgh, L. H. (1950). In Clinical Nutrition, p. 689. [N. Jolliffe, F. F. Tisdall and P. R. Cannon, editors.] New York: Paul B. Hoeber Inc., Medical Book Department of Harper Brothers.

Passmore, R., Strong, J. A. \& Ritchie, F. J. (1958). Brit. F. Nutr. I2, I 13.

Strong, J. A., Passmore, R. \& Ritchie, F. J. (1958). Brit. F. Nutr. 12, I05.

Trapp, H. (1850). Beiträge zur Kenntniss der Veränderungen welche der Urin in Krankheiten erleidet. Thesis, Giessen. Quoted by Vogel, J. (1854). Arch. V'er. gem. Arb. wiss. Heilk. 1, 96. 